\title{
Indonesian Public Policy in the Post-truth Era
}

\author{
Nuraeni \\ Department of International Relations \\ Universitas Padjadjaran \\ Bandung, Indonesia \\ nuraeni@unpad.ac.id
}

\begin{abstract}
Globalization has driven the availability of access to abundant information. Nevertheless, the easier people in getting the information is not identical with the ability to gain the logical and critical understanding.The greatest battle of public office elections and the implementation of policies are against the hoaxes and also the perceptions raised from those fake news. This trend is also happening in several other parts of the world such represented by the phenomenon of Brexit and Donald Trump's victory. Apparently this pattern has been occurring in Indonesia since 2014 presidential elections until now. Government policies pose many obstacles regarding the social perceptions, beliefs and values that has been shaped through personal preference to the news mainly spread through social media. There are lack of confirmation to the substantial aspect of the policies. Those are the symptoms of the Post-truth Era.
\end{abstract}

Keywords-Indonesian Public Policy, Globalization, Social Media, Post-truth, hoax, Populism

\section{INTRODUCTION}

For 72 years of independent, Indonesia has experienced different public policy characteristics under seven presidents. The differences cannot be separated from various aspects that has influenced decision making and the formulation of public policy both practical and academic. The challenges faced by each leader have been also shaping their perspectives. Sukarno have had to work hard in nurturing newborn nation. Soeharto, who could not escape from the dynamics of cold war era. Habibie grappled with the transitional period of democracy. Abdurrahman Wahid with the strong commitment to reestablished awareness on pluralistic destiny of Nusantara. Susilo Bambang Yudhoyono face the challenges of the millennium era. President Joko Widodo administration has shown the persistence to boost development while seeking equity. Various policy packages and flagship programs in some priority sectors such as infrastructure from Western to East Indonesia have been launched and directly supervised by the president. Significant achievements began to be recognized regionally and globally. However, thisgovernment has grown at the same time with the birth of the post-truth era. For example is the debate that arise related to government policy on national immunization/vaccination program that cause pros and cons. Some other programs related to the taxation, employment also about civil society organizations regulation also experienced the similar problem. On the one hand, government must be able to provide the fair and effectively implemented policies, on the other hand have to deal with various perceptions and mindset of the citizens that potentially hamper the realization of vision and mission that has been designed.

\section{Purpose, SignificAnCE, AND Methode}

This paper will explore how the Indonesian public policy under Joko Widodo administration has to deal with the challenges in Post-truth era. It is important to highlight millennial public discourses are able to contribute constructive as well as destructive aspect to the public policy formation and implementation. The discussion is going to be delivered as library research study from the political philosophy perspectives.

\section{DISCUSSION}

Political life is formed in the context of human needs in shaping society. Governance is one of the consequences of politics. The main problem of political thinkers is to understand the tension between what should be and what happens actually. In the beginning political philosophy has been inspired by the real context of human life. Later, some philosophers suggest the models of human relations. Nevertheless, there is a tendency of practical politics to walk across the street with political philosophy [1]. Plato has mentioned that public perspective (doxa) is always posed the challenge to maintain the truth (episteme). Understanding public sphere is as a key concept in earning the dynamics that occur in political relationships that certainly affect the concepts and practices of government itself. Hardiman argued that tendency can be traced in daily life. Contemporary government must be ready for 24 hours, 7 days, 365 days is constantly being watched by its people. Various institutions and legal tools are born from the process 
described above. For example, currently ordinary citizens may object to a rule or legislation established by both the executive and the legislature through the Judicial Review in the Constitutional Court [2].

From this point, public sphere encompasses all kinds of spaces within which it allows the public to express their views independently and openly regarding almost every issue, including government policy. Rapid information and communication technology have also made an important contribution to the effect of public spaces on governance processes. Today's public opinion is so easily spread and transformed into so many facet, including as a new powerful instrument cannot be underestimated in contemporary politics. In the United States, public opinion has had succeeded in pushing to end of the Vietnam War. In Germany, the reunification of East and West Germany was born not from the will of the elite but people movement. In Indonesia, for sure technology has leveraged public opinion as undeniable instrument to criticize government policy. Some phenomenon has been confirmed the trend. The viral movement of Coins For Prita on Facebook are raised to support Prita and also criticizing the unfair judicial process. The political temperature in Indonesia today can be discovered in social media platforms such as Twitter and Facebook.

The public space is no longer viewed as the result of a certain ideological reconstruction which the society inevitably must accept and run. The concept of social contract as the basis of the legitimacy of a government is no longer a once and eternal one, but a dynamic process. On the one hand, the public sphere is also very vulnerable to the arena of attraction to the power of elite groups that use the voice of the people. On the other hand, it is only through this public space that the people can directly supervise and also conduct various activities that can prevent the occurrence of abuse of power or subvert an absolute power.

In the beginning of social media activism, there are optimism that regardless some flaws, the ongoing democratization in Indonesia has shown some positive progress. Peaceful general election processes that followed by many parties is supporting the argument. Besides the direct presidential election which is also followed by the direct election of local public leaders are another evidences in the positive democratization stage in Indonesia. Furthermore, freedom of expression and conveyed aspirations in the community also increased. Injustice is not something can be hidden anymore. Some marginalized people has found their voice to claim their rights. The government is an easy target to be criticize, particularly regarding unfair policy from the public perspectives. In this context, public sphere is important in exercising direct checks and balances in domestics politics. It also can restrict the practices in politics and government as an exclusive right of a group of elites. For some elites, public space cracking becomes an effective way. In some countries, government is officially banning and blocking social media sites that are considered potentially undermine the legitimacy of the oligarchy.

The optimism has been put into question when the fact of internal conflictual public sphere. The fight is not just public opinion vs government, but public opinion vs public opinion. Unfortunately, public opinion that had been predicted to become a critical instrument actually developed into a fierce irrational debate and no longer critical. Populism is now trending for politicians who use dominant public opinion in formulating their policies and obviouslu do not care that in the long run the policy would be detrimental. The post-truth era in political life is characterized by an exchange between the political interests and dominant public preference that are very likely to contain many biases, such as majority bias, gender bias and so on. It will burden for the government in positioning to take a policy that is not populist.

Haryatmoko described that such phenomenon also happened in other countries. In Indonesia for some reasons politics has a bad image because it is often associated with the pursuit of power by justifying all means. The image is not only embedded in the elite of the executive, legislative, and judiciary but also the bureaucrats from the higher to lower level, and in general the behavior of the public officer which are highlighted reflects the transactional political process. It is contradictory with the basic principles of the modern state that government is public servant. Sometimes these principles form other issues. For example the debate on the principle of democracy which on the one hand creates popular participation but also enables the tyranny of the majority or creates legitimacy against a group of elites who claim to gain legitimacy from the people. In real politics in Indonesia we often hear the term procedural democracy.[3]

Government not only carries out formal institutional principles but is also related to ethical issues. Hannah Arendt suggest that public sphere is the arena for justice. The relation between government and its people is not "domination over" but "ruler over" [4]. Habermas 
also argued that it is necessary to understand the relation of power and the sovereignty of the people not merely from the procedural side but also contain a continuous process of discursive relations in such a way that the logic of political action shared. For Habermas as a critical theorist, it is important to understand politics and government not only as a mere managerial activity but also a space of emancipation for all elements of the country, especially the people [5]. Will Kymlicka notion can be added that the deliberation of emancipation should also accommodate the diversity itself. Currently there is not much homogeneous country composition, not even korea or japan can isolate itself from ${ }^{[1}$ human mobilization and ideas that also affect the $\mathrm{e}^{[2}$ composition of its population. The issue of racial, ${ }^{[3]}$ religious and ethnic diversity must be a very important consideration for every government in ${ }_{[6]}^{[5}$ the world today [6].

\section{CONCLUSION}

Public Policy and Public opinion at this time can be analogized as two inseparable elements in development and political life around the world including Indonesia. It should be noted that both elements must be in a proportional relationship. Joko Widodo's administration is presumably trying to restore a proportional balance between the two through some real policies as well as opening up discursive space.

\section{REFERENCES}

Haryatmoko, 2014: pp 7-8:

Hardiman, 2001: pp114-15.

Haryatmoko, Ibid.

Arendt: 1959, pp 23-69,

Habermas

Kymlicka. 